p-ISSN 1693-9484, $e$-ISSN : 2621-8313

Majalah Ilmiah Bahari Jogja (MIBJ)

Vol. 18 No. 2, Juli $2020 \quad$ (8-18)

DOI : $10.33489 /$ mibj.v18i2.242

(C2020 Sekolah Tinggi Maritim Yogyakarta

\title{
Implikasi Kecerdasan Emosional Terhadap Prestasi Kerja Dosen Sekolah Tinggi Maritim Yogyakarta (STIMARYO)
}

\author{
Suyanti ${ }^{* *}$, Sahudiyono ${ }^{1}$ \\ ${ }^{1}$ Sekolah Tinggi Maritim Yogyakarta, Jl. Magelang KM 4.4, Yogyakarta 55284, \\ Indonesia \\ * Corresponding Author. E-mail : syandanish106@gmail.com. Telp : +62 813-5784-0120
}

\begin{abstract}
Abstrak
Penelitian ini meneliti implikasi kecerdasan emosional terhadap prestasi kerja dosen Sekolah Tinggi Maritim Yogyakarta (STIMARYO). Masalah yang diteliti adalah pengaruh faktor kecerdasan emosional terhadap prestasi kerja dosen Sekolah Tinggi Maritim Yogyakarta. Penelitian ini merupakan penelitian kuantitatif yang menggunakan data primer sebagai sumber datanya. Data diperoleh dari penyebaran kuesioner kepada karyawan Sekolah Tinggi Maritim Yogyakarta. Data dianalisis menggunakan regresi linier sederhana. Hasil penelitian mendapatkan kesimpulan ada pengaruh positif dan signifikan dari faktor kecerdasan emosional terhadap prestasi kerja dosen Sekolah Tinggi Maritim Yogyakarta. Adanya pengaruh positif, diketahui dari nilai koefisien regresi sebesar positif 0,549. Adanya pengaruh signifikan diketahui dari hasil uji $\mathrm{F}$ dan uji t yang mendapatkan nilai signifikansi $0,004(<0,05)$ yang berarti bahwa variabel bebas mempunyai pengaruh yang signifikan terhadap variabel terikat.
\end{abstract}

Kata Kunci: Implikasi, Kecerdasan Emosional, Prestasi Kerja

\section{Abstract}

This study examines the implications of emotional intelligence on the work performance of Yogyakarta Maritime College (STIMARYO) lecturers. The problem under study is the influence of emotional intelligence factors on Yogyakarta Maritime College lecturers' work performance. This research is a quantitative study that uses primary data as a source of data. Data were obtained from distributing questionnaires to Yogyakarta Maritime College employees. Data were analyzed using simple linear regression. The results of the study concluded that there were positive and significant factors of intelligence on the work performance of Yogyakarta Maritime College lecturers. The existence of a positive influence is known from the positive regression coefficient 0.549 . Significant differences were obtained from the results of the $F$ test and t test which obtained a significance value of $0.004(<0.05)$

Keywords: Implications, Emotional Intelligence, Job Performance 


\section{PENDAHULUAN}

Dahulu orang menganggap kecerdasan intelektual sebagai penentu utama kesuksesan seseorang. Namun, belakangan ini, pembicaraan tentang kecerdasan emosional juga mengemuka, yang intinya menyatakan bahwa inteligensia saja tidak cukup. Seseorang harus pandai mengelola emosi dengan baik, jika ingin mendapatkan kesuksesan dalam bidang apapun yang digelutinya.

Orang yang memiliki kecerdasan emosional berarti terlibat dalam kapasitas untuk merasakan emosi, berasimilasi dengan emosi, serta memahami informasi dari emosi-emosi tersebut. Berkaitan dengan itu kecerdasan emosional bisa meningkatkan kemampuan menyelesaikan masalah dikarenakan orang yang memiliki kecerdasan emosional memiliki kemampuan untuk merasakan emosi dengan benar, untuk mengakses dan mengelola emosi guna membantu pikiran, untuk memahami emosi, serta untuk merefleksikan emosi sehingga bisa mengatur emosi dan pertumbuhan intelektual.

Kecerdasan emosional menjadi penting karena kecerdasan emosional memungkinkan seseorang tidak hanya memproses hal-hal yang sarat dengan muatan informasi secara efektif, namun mereka juga menggunakan informasi tersebut untuk mengatur dunia sosialnya. Kecerdasan emosional sangat membantu untuk menyelesaikan masalah karena kecerdasan emosional merupakan kemampuan untuk memikirkan dan menggunakan emosi untuk meningkatkan kemampuan berpikir.

Seorang dosen sekarang ini dituntut untuk membuat karya-karya ilmiah yang dianggap beban berat karena dituntut dalam kualitas yang tinggi dan dalam jumlah yang banyak. Dosen harus menulis dalam waktu yang rutin, sesuai dengan jenjang kepangkatan yang dimilikinya. Jika tidak, tunjangan dosen tidak akan diterimanya, kenaikan pangkat akan tertunda, dan sejumlah konsekuensi lainnya.

Kewajiban menulis ini tidak hanya menjadi beban intelektual, tetapi juga menjadi beban emosional dosen. Seorang dosen yang memiliki kemampuan intelegensi yang tinggi, kadang mengalami kesulitan untuk memenuhi tugas membuat karya ilmiah karena tidak mampu mengendalikan emosinya. Emosi yang muncul di sini adalah berupa rasa stres karena harus menulis karya ilmiah dengan kualitas tinggi dan dalam waktu yang terbatas. Rasa stres ini, membuat dosen "mati" daya pikirnya. Dalam situasi ini, kecerdasan emosi penting untuk mendorong kreativitas menulis, merubah suasana hati dari mood negatif menjadi mood positif sehingga meningkatkan pemikiran kreatif dosen.

Berkaitan dengan itu ditengarai kecerdasan emosional akan mempengaruhi prestasi kerja dosen. Tulisan ini akan meneliti seberapa besar pengaruh kecerdasan emosional terhadap prestasi kerja dosen dalam kegiatan tulis-menulis karya tulis ilmiah Sekolah Tinggi Maritim Yogyakarta (STIMARYO).

\section{KAJIAN LITERATUR}

Prestasi kerja merupakan salah satu masalah manajemen sumber daya manusia yang selalu menjadi perhatian. Istilah prestasi kerja mengandung berbagai macam pengertian. Prestasi kerja dapat ditafsirkan sebagai "arti penting suatu pekerjaan"; "tingkat keterampilan yang diperlukan"; "kemajuan dan tingkat 
penyelesaian“ dari suatu pekerjaan (Panggabean, 2002). Di lain pihak menurut Simamora (2003) prestasi kerja karyawan adalah tingkat pencapaian pekerjaan oleh karyawan.

Guna mendapatkan kontribusi karyawan yang optimal, manajemen harus memahami secara mendalam strategi untuk mengelola, mengukur dan meningkatkan prestasi kerja, yang dimulai dengan terlebih dahulu menentukan tolok ukur prestasi kerja. Melalui tolok ukur tersebut, dilakukan pengukuran prestasi kerja.

Sembilan manfaat pengukuran performansi untuk tingkat perusahaan menurut Sugiyanto (1997) adalah:

1. Perusahaan dapat menilai efisiensi penggunaaan sumber daya dalam menghasilkan barang atau jasa.

2. Pengukuran performansi berguna untuk pengukuran sumber daya yang baik untuk jangka panjang maupun jangka pendek.

3. Usaha pengukuran performansi dapat dipakai untuk menyusun kembali tujuan ekonomi dan non ekonomi perusahaan.

4. Sebagai dasar pengukuran performansi dimasa yang akan datang.

5. Strategi untuk meningkatkan performansi dapat ditentukan berdasarkan perbedaan antara tingkat performansi yang direncanakan dengan performansi yang diukur.

6. Dapat dipakai untuk membandingkan kinerja manajemen dalam perusahaan dengan perusahaan sejenis maupun dalam lingkup nasional.

7. Nilai-nilai performansi yang dihasilkan dari pengukuran performansi dapat digunakan dalam perencanaan tingkat keuntungan perusahaan.

8. Pengukuran performansi akan menciptakan tindakan persaingan.

9. Penawaran kolektif dapat dicapai lebih rasional saat diperoleh perkiraan performansi.

Setiap manusia pasti memiliki emosi. Emosi pada prinsipnya menggambarkan perasaan manusia menghadapi berbagai situasi yang berbeda. Oleh karena itu emosi merupakan reaksi manusiawi terhadap berbagai situasi nyata. Maka sebenarnya tidak ada 'emosi baik' atau 'emosi buruk' (Dio Martin, 2003).

Dewasa ini dikenal istilah kecerdasan emosional/emotional quotient (EQ). Kecerdasan emosional pada prinsipnya menggambarkan perasaan manusia menghadapi berbagai situasi yang berbeda (Martin, 2003). Istilah ini berkaitan dengan kemampuan seseorang mengelola emosinya.

Pembahasan tentang EQ diawali oleh seorang psikolog Yale, Peter Salovey dan seorang professor dari Universitas New Hampshire, John Mayer yang pada tahun 1990. Mereka mencetuskan sebuah ide tentang emotional quotient. Mereka mendefinisikan EQ sebagai "kemampuan untuk memahami diri sendiri, untuk berempati terhadap perasaan orang lain dan untuk mengatur emosi yang secara bersamaan berperan dalam peningkatan taraf hidup seseorang". Semula ide ini hanya diperkenalkan disekitar lingkungan pendidikan saja. Kemudian Daniel Goleman memperkenalkan terminologi EQ dalam bukunya "Emotional Intelligence, Why It can Matter More than IQ?", sehingga akhirnya istilah ini menjadi terkenal tidak saja di dunia pendidikan (Dio Martin, 2003). 
Menurut Reuve Bar-On (Melianawati et. al., 2001) kecerdasan emosional merupakan kemampuan mengatur perasaan dengan baik, mampu memotivasi diri sendiri, serta berempati ketika menghadapi gejolak emosi diri sendiri maupun orang lain.

Cooper dan Swaf (Melianawati et. al., 2001) berpendapat bahwa kecerdasan emosional adalah kemampuan merasakan, memahami dan secara efektif menetapkan daya dan kepekaan emosi sebagai sumber energi, informasi, koneksi dan pengaruh yang manusiawi.

Menurut Salovey dan Mayer (Melianawati et.al., 2001) kecerdasan emosional adalah himpunan bagian dari kecerdasan sosial yang melibatkan kemampuan memantau perasaan dan emosi baik pada diri sendiri maupun pada orang lain, memilah-milahnya dan menggunakan informasi ini untuk membimbing pikiran dan tindakan.

Menurut Goleman (2005), kecerdasan emosional adalah kecakapan emosi yang meliputi kemampuan untuk mengendalikan diri sendiri dan memiliki daya tahan ketika menghadapi rintangan, mampu mengendalikan impuls dan tidak cepat merasa puas, mampu mengatur suasana hati dan mampu mengelola kecemasan agar tidak menganggu kemampuan berfikir, serta mampu berempati dan berharap.

Kecerdasan emosional ditengarai merupakan salah satu faktor yang mempengaruhi prestasi kerja, karena manusia dengan kecerdasan emosi yang baik, dapat memecahkan suatu masalah serta fleksibel dalam situasi dan kondisi yang kerap berubah. Di samping itu individu yang memiliki kecerdasan emosional juga mampu membina hubungan yang baik dengan orang lain dan mudah mengenali emosi pada orang lain dan penuh perhatian, sehingga semua itu membuat prestasi kerjanya dapat terjaga.

Berdasarkan teori di atas, diberikan hipotesis sebagai berikut: "Ada pengaruh positif dan signifikan dari faktor kecerdasan emosional terhadap prestasi kerja dosen."

\section{METODE PENELITIAN}

\section{Waktu dan Tempat Penelitian}

Penelitian ini dilaksanakan pada Bulan Oktober-Desember 2018 pada Akademi Maritim Yogyakarta (AMY).

\section{Populasi, Sampel dan Teknik Sampling}

Populasi adalah keseluruhan anggota penelitian, sedangkan sampel adalah bagian dari populasi yang dijadikan objek penelitian (Santoso, 2007: 12). Populasi pada penelitian ini adalah seluruh dosen Akademi Maritim Yogyakarta yang berjumlah 37 orang. Karena jumlah populasi tidak besar, maka semua anggota populasi dijadikan sampel. Teknik pengambilan sampel yang demikian disebut teknik sensus sampling, yaitu cara pengambilan sampel dengan menjadikan seluruh anggota populasi sebagai sampel. Teknik ini digunakan jika jumlah populasi terbatas.

\section{Target Sasaran}

Target sasaran penelitian ini adalah dosen yang aktif melakukan kegiatan belajar mengajar di Akademi Maritim Yogyakarta. 


\section{Variabel Penelitian}

Variabel dalam penelitian adalah sebagai berikut: Variabel Dependen (Y),Variabel dependen dalam penelitian ini adalah prestasi kerja karyawan. Variabel Independen (X), Variabel independen dalam penelitian ini adalah faktor kecerdasan emosional.

\section{Analisis Data}

Agar kuesioner yang diberikan dapat mengukur kenyataan yang sebenarnya di lapangan, dilakukan uji validitas dan reliabilitas instrumen (Santoso, 2007). Uji asumsi klasik normalitas dan linieritas juga digunakan untuk menguji data yang dikumpulkan (Santoso, 2007). Data yang terkumpul dianalisis dengan menggunakan bantuan program SPSS for Windows version 19. Analisis yang dilakukan antara lain analisis regresi linier sederhana, uji $\mathrm{F}$, uji koefisien determinasi $\left(\mathrm{R}^{2}\right)$, dan uji t.

\section{HASIL DAN PEMBAHASAN}

\section{Uji Validitas dan Reliabilitas}

Hasil pengujian validitas instrumen mendapatkan hasil bahwa setiap item pertanyaan memiliki nilai corrected total item correlation di atas 0,3. Berdasarkan pendapat Azwar (2009), jika nilai corrected total item correlation $\geq 0,3$ maka item adalah valid, maka dapat disimpulkan bahwa semua item yang diuji (13 item untuk variabel kecerdasan emosional dan 13 item untuk variabel prestasi kerja) adalah valid dan dapat digunakan untuk pengumpulan data.

Hasil uji reliabilitas juga menunjukkan bahwa instrumen reliabel, sehingga dapat digunakan dalam penelitian. Hal ini diketahui dari output uji reliabilitas yang mendapatkan nilai koefisien reliabilitas variabel $>0,7$.

Hasil uji validitas dan reliabilitas menunjukkan semua item lolos uji, sehingga dapat digunakan untuk mengumpulkan data penelitian.

\section{Pengujian Asumsi Klasik}

\section{a. Uji Normalitas Data}

Uji normalitas bertujuan untuk mengetahui apakah sampel berasal dari populasi dengan sebaran distribusi normal (Azwar, 2009). Uji ini dilakukan dengan uji Kolmogorov Smirnov Goodness of Fit yaitu dengan menguji skor total nilai dari masing-masing skala. Berdasarkan uji normalitas diperoleh nilai K-S Z untuk variabel kecerdasan emosional $=1,114$ dengan taraf signifikansi sebesar 0,167 ( $p>0,05$ ), artinya data berdistribusi normal. Nilai K-S Z untuk variabel prestasi kerja $=1,239$ dengan taraf signifikansi sebesar 0,093 $(\mathrm{p}>0,05)$, artinya data berdistribusi normal. Dari hasil pengujian ini diketahui bahwa baik data kecerdasan spiritual maupun prestasi kerja berdistribusi normal sehingga layak digunakan sebagai data penelitian.

\section{b. Uji Linieritas}

Uji linieritas dilakukan untuk mengetahui apakah kedua variabel yang dikenai prosedur analisis korelasi menunjukkan hubungan yang linier. Hasil uji linieritas menunjukkan bahwa ada hubungan linier antara variabel kecerdasan emosi dengan variabel prestasi kerja. Hal ini diketahui dari nilai signifikansi pada 
baris linearity di tabel anova nilainya $<0,05$ sehingga dapat disimpulkan data bersifat linier (memenuhi syarat linieritas).

\section{Uji Hasil}

Dari uji regresi linier sederhana yang dilakukan, diperoleh hasil sebagai berikut:

Tabel 1. Hasil Uji Regresi Linier Sederhana

\begin{tabular}{ccccc}
\hline Variabel & $\begin{array}{c}\text { Koefisien } \\
\text { Regresi }\end{array}$ & thitung & Signifikansi & Keterangan \\
\hline Kecerds. emosional & 0,549 & 3,116 & 0,004 & Signifikan \\
Konstanta & & & \\
$\mathrm{R}^{2}$ & & 16,611 & \\
Fhitung & & 0,466 & \\
\hline
\end{tabular}

Sumber: Data primer diolah.

Dari hasil pengolahan data di atas, diperoleh persamaan berikut:

$\mathrm{Y}=16,611+0,549 \mathrm{X}+\mathrm{e}$

Persamaan yang dihasilkan tersebut kemudian diuji dengan uji $\mathrm{F}$ atau yang dikenal dengan uji model/uji anova, yaitu uji untuk melihat pengaruh variabel bebas terhadap variabel terikat. Dengan kata lain uji F digunakan untuk menguji apakah model regresi yang dihasilkan baik/signifikan atau tidak baik/non signifikan.

Hasil pengujian mendapatkan nilai signifikansi 0,004 . Nilai $0,004<0,05$ yang berarti bahwa variabel bebas mempunyai pengaruh yang signifikan terhadap variabel terikat. Artinya ada pengaruh signifikan dari variabel kecerdasan emosional terhadap pretasi kerja dosen STIMARYO Yogyakarta.

Hasil uji $\mathrm{F}$ ini didukung oleh uji t. Apabila nilai prob. $t$ hitung (ouput SPSS ditunjukkan pada kolom sig.) lebih kecil dari tingkat kesalahan (alpha) 0,05 (yang telah ditentukan) maka dapat dikatakan bahwa variabel bebas (dari $\mathrm{t}$ hitung tersebut) berpengaruh signifikan terhadap variabel terikatnya, sedangkan apabila nilai prob. $\mathrm{t}$ hitung lebih besar dari tingkat kesalahan 0,05 maka dapat dikatakan bahwa variabel bebas tidak berpengaruh signifikan terhadap variabel terikatnya (Astriawati, 2016). Dari hasil uji t diketahui nilai signifikansinya adalah $0,004(<0,05)$, artinya ada pengaruh yang signifikan dari variabel kecerdasan emosional terhadap prestasi kerja karyawan.

Selanjutnya dilakukan uji koefisien determinasi $\left(\mathrm{R}^{2}\right)$ yang mendapatkan nilai sebesar 0,466. Artinya variansi variabel terikat yang dapat dijelaskan variabel bebas sebesar $46,6 \%$ sedangkan sisanya sebesar 53,4\% dijelaskan oleh variabel lain yang tidak diteliti dalam penelitian ini.

\section{Uji Hipotesis}

Hasil uji $\mathrm{F}$ dan uji $\mathrm{t}$ jelas menunjukkan ada pengaruh yang signifikan dari variabel bebas terhadap variabel terikat. Hal ini diketahui dari nilai signifikansi 
kedua pengujian itu yang bernilai $<0,05$. Nilai pengaruhnya adalah positif, hal ini diketahui dari nilai koefisien regresi sebesar positif 0,549.

Berdasarkan hasil pengujian tersebut, dapat diketahui bahwa ada pengaruh positif dan signifikan dari faktor kecerdasan emosional terhadap prestasi kerja dosen (hipotesis terbukti).

\section{Pembahasan}

Dari hasil analisis di atas dapat diketahui bahwa terdapat pengaruh yang positif dan signifikan dari kecerdasan emosional terhadap prestasi kerja dosen. Dalam praktek kerja dosen, hal tersebut dapat dijelaskan sebagai berikut.

Seorang dosen, sekarang ini mempunyai kewajiban untuk melakukan penelitian dan publikasi ilmiah guna meningkatkan keterampilan dalam menulis. Hal ini sejalan dengan Tri Dharma Perguruan Tinggi. Selain itu, karya ilmiah ini juga merupakan bagian dari syarat mendapatkan tunjangan dosen serta kenaikan jabatan fungsional akademik, sebagaimana diatur dalam Permenpan dan Reformasi Birokrasi No. 46 Th. 2013 tentang Jabatan Fungsional Dosen dan Angka Kreditnya.

Dalam Tri Dharma Perguruan Tinggi, dikatakan bahwa dosen bukan hanya sebuah profesi, tetapi juga seorang akademisi, seorang ilmuwan yang wajib mengembangkan ilmunya. Tidak hanya mengembangkan ilmu, dosen juga wajib mengaplikasikan ilmunya tersebut kepada masyarakat. Semua itu membutuhkan katerampilan dosen untuk menulis sebagai fasilitas bagi dosen untuk menyampaikan gagasan-gagasan dan temuannya kepada masyarakat.

Di lain pihak, untuk mendapatkan tunjangan dosen dan kenaikan pangkat, dosen disyaratkan untuk mengumpulkan angka kredit kumulatif (kum) yang salah satunya berasal dari penulisan karya ilmiah. Angka kredit kumulatif adalah angka kredit yang berasal dari seluruh butir kegiatan dalam rangka memperoleh serta melaksanakan pendidikan dan pengajaran serta melaksanakan pengabdian pada masyarakat.

Nilai angka kredit kumulatif untuk masing-masing jenjang kepangkatan dosen adalah:

Tabel 2. Jenjang Jabatan dan Pangkat Dosen

\begin{tabular}{|c|c|c|c|c|}
\hline \multirow[t]{2}{*}{$\begin{array}{l}\mathrm{N} \\
\mathrm{O}\end{array}$} & \multirow[t]{2}{*}{$\begin{array}{l}\text { Jenjang } \\
\text { Jabatan }\end{array}$} & \multirow[t]{2}{*}{$\begin{array}{l}\text { Jenjang Pangkat/ } \\
\text { Golongan Ruang }\end{array}$} & \multicolumn{2}{|c|}{$\begin{array}{c}\text { Angka Kredit yang } \\
\text { Dipersyaratkan }\end{array}$} \\
\hline & & & $\begin{array}{l}\text { Kumulati } \\
\text { f Minimal }\end{array}$ & $\begin{array}{c}\text { Per } \\
\text { Jenjang }\end{array}$ \\
\hline 1 & Asisten Ahli & Penata Muda Tk. I, III/b & 150 & - \\
\hline \multirow[t]{2}{*}{2} & \multirow[t]{2}{*}{ Lektor } & Penata, III/c & 200 & 50 \\
\hline & & Penata Tk. I, III/d & 300 & 100 \\
\hline \multirow[t]{3}{*}{3} & \multirow[t]{3}{*}{ Lektor Kepala } & Pembina, IV/a & 400 & 100 \\
\hline & & Pembina Tk. I, IV/b & 550 & 150 \\
\hline & & Pembina Utama Muda, IV/c & 700 & 150 \\
\hline \multirow[t]{2}{*}{4} & \multirow[t]{2}{*}{ Guru Besar } & Pembina Utama Madya, IV/d & 850 & 150 \\
\hline & & Pembina Utama, IV/e & 1.050 & 200 \\
\hline
\end{tabular}

Majalah Ilmiah Bahari Jogja 14 | http://jurnal.amy.ac.id/index.php/MIBJ/ 
Sumber: Permenpan dan Reformasi Birokrasi No. 46 Th. 2013 tentang Jabatan Fungsional Dosen dan Angka Kreditnya.

Nilai kum sebagaimana ditentukan di atas, harus dicapai dosen. Salah satu penyumbangnya adalah dari publikasi karya ilmiah, baik jurnal nasional maupun jurnal internasional. Adapun nilai kredit untuk publikasi karya ilmiah adalah:

1. Jurnal ilmiah nasional

a. Terakreditasi angka kredit 25 .

b. Tidak terakreditasi tetapi terindeks DOAJ (ditulis dalam bahasa Indonesia, angka kredit 15.

c. Tidak terakreditasi tetapi terindeks DOAJ (ditulis dalam bahasa Inggris), angka kredit 20.

d. Tidak terakreditasi (maksimal 25\% angka kredit yang diperlukan untuk profesor), angka kredit 10.

Syarat tulisan dapat diberi angka kredit adalah dapat ditelusuri secara online (jurnal ber-websitel direpositori di laman resmi perguruan tinggi), dengan batas kepatutan 2 (dua) artikel/semester untuk jurnal yang tidak terakreditasi dan 1 (satu) artikel/semester untuk jurnal yang terakreditasi.

2. Jurnal ilmiah internasional

a. Jurnal internasional bereputasi

1) Terindeks di Scopus dan Web of Science

2) Memiliki faktor dampak (impact factor) dari ISI Web of Science (Thomson Router) atau Scimago Journal Rank (SJR)

3) Angka kredit 40.

b. Jurnal internasional

1) Terindeks di Scopus dan Web of Science

2) Tidak memiliki faktor dampak (impact factor) dari ISI Web of Science (Thomson Router) atau Scimago Journal Rank (SJR)

3) Angka kredit 30.

c. Jurnal internasional

1) Belum terindeks di data base Scopus dan Web of Science tapi terindeks di DOAJ, CABI, Copernicus, EBSCO.

2) Angka kredit maksimal 20.

d. Tidak terakreditasi (maksimal 25\% angka kredit yang diperlukan untuk profesor), angka kredit 10.

Aturan sebagaimana dikeluarkan di atas harus ditaati dosen yang ingin mendapatkan kenaikan pangkat. Namun banyak dosen yang tidak mampu memenuhi syarat itu, sehingga menyebabkan dosen menumpuk di golongan tertentu, misalnya golongan III/b akibat tidak memenuhi kewajiban membuat karya ilmiah.

Karena dosen terhambat untuk naik pangkat karena tidak membuat karya ilmiah, banyak dosen yang mempunyai asumsi bahwa kebijakan mengharuskan dosen membuat karya ilmiah untuk syarat kenaikan pangkat adalah kebijakan yang menyengsarakan dosen dan berdampak pada gagalnya pelaksanaan tugas utama dosen untuk mengajarkan ilmunya kepada mahasiswa. Dosen mendukung upaya pemerintah untuk meningkatkan kualitas dan profesionalitas dosen, tetapi 
jika peraturan ini terus diberlakukan, justru akan membuat para dosen stres, yang akhirnya berakibat kepada penurunan kinerjanya.

Pendapat lain yang menolak kebijakan kewajiban pembuatan karya ilmiah adalah bahwa dosen sudah sibuk dengan tugas utamanya dan masalah administrasi, sehingga tidak mudah untuk bisa meluangkan waktu meneliti. Apalagi, selama ini tidak ada pelatihan yang intensif bagi dosen untuk membuat karya ilmiah, tetapi tuntutan pemerintah pada dosen amat tinggi.

Di sisi lain, pemerintah justru tetap mewajibkan dosen melakukan publikasi karya ilmiah sesuai dengan persyaratan yang telah ditentukan. Persyaratan kelulusan bagi mahasiswa magister dan doktor dalam standar nasional pendidikan tinggi juga diberlakukan syarat yang serupa. Untuk memenuhi kebutuhan tersebut diperlukan penerbitan lebih dari 8.000 jurnal ilmiah yang terakreditasi nasional. Akreditasi jurnal ilmiah adalah pengakuan resmi atas penjaminan mutu jurnal ilmiah melalui kegiatan penilaian kewajaran, penyaringan naskah, kelayakan pengelolaan, dan ketepatan waktu penerbitan jurnal ilmiah.

Menghadapi kenyataan ini banyak dosen yang stres, sedih, bahkan putus asa. Ada juga dosen yang tidak peduli dengan kegiatan menulis karya ilmiah dan pasrah jika pihak kampus menegurnya, bahkan jika pihak kampus terpaksa memberhentikannya sebagai dosen. Muncul juga fenomena baru di kalangan dosen yang sudah mempunyai golongan kepangkatan yang tinggi, mengajukan penurunan pangkat agar tidak terlalu terbebani dengan tuntutan penulisan karya ilmiah di level pangkatnya semula. Misalnya dosen yang pangkatnya lektor kepala minta diturunkan jabatannya menjadi lektor saja, agar tidak terlalu tinggi beban menulisnya.

Pada saat inilah kecerdasan emosional sangat diperlukan. Karena apabila dosen tidak memiliki kecerdasan emosional, maka ketika menghadapi beban berat untuk menyelesaikan karya ilmiah di tengah waktu yang semakin mendesak, akan membuat dosen menjadi stres. Jika stres ini bisa dikelola dengan baik, maka ia akan menjadi energi positif yang membawa seluruh daya pikir dan daya juang dosen untuk menyelesaikan karya ilmiahnya. Akan tetapi jika yang terjadi adalah sebaliknya, maka rasa stres itu akan membuat dosen "mati" daya pikir dan daya juangnya. Dosen akan mengalami bad mood dalam menulis sehingga penulisan tugas karya ilmiahnya tidak selesai. Dosen bisa juga mengalami dampak lanjutan dari rasa stresnya berupa gangguan emosi seperti ingin marah kepada siapa saja tanpa ada alasan yang jelas atau merasa sedih karena merasa tak berdaya. Rasa stres juga dapat berakibat kepada fisik dosen yang bisa mengalami gangguan fisik akibat stres seperti pusing, mual dan muntah, bahkan sakit yang lebih parah seperti darah tinggi dan jantung.

Kecerdasan emosional adalah kemampuan merasakan, memahami dan secara selektif menerapkan daya dan kepekaan emosi sebagai sumber energi, informasi koneksi dan pengaruh yang manusiawi. Kecerdasan emosional memberi informasi penting yang menguntungkan, umpan balik dari hati yang dapat memunculkan kreativitas, membuat bersikap jujur pada diri sendiri, memberikan panduan nurani bagi hidup dan karier, membantu menghadapi kemungkinan yang tidak terduga dan dapat menyelamatkan diri dari kehancuran. 
Berdasarkan nilai-nilai kecerdasan emosional yang dimilikinya, dosen yang mengalami masalah dalam pembuatan karya ilmiah akan dapat mengatasi rasa frustasinya, mengontrol desakan hati dan mengatur suasana hatinya (mood) sehingga rasa putus asa dan stres yang dirasakannya justru dapat digunakannya sebagai sumber energi positif untuk menyelesaikan kewajibannya membuat karya ilmiah. Dosen akan merubah mood negatifnya menjadi mood positif untuk mencari cara mengatasi kesulitannya dalam menulis karya ilmiah. Ia akan menggunakan waktunya untuk membaca buku, membaca artikel atau bertanya lepada orang lain yang lebih menguasainya. Semua itu menyebabkan ia bisa menyelesaikan kewajiban menulis karya ilmiah. Oleh karena itulah, kecerdasan emosional mempunyai pengaruh positif dan signifikan terhadap prestasi kerja dosen.

\section{SIMPULAN}

Berdasarkan analisis data yang dilakukan, dapat disimpulkan bahwa ada pengaruh positif dan signifikan dari faktor kecerdasan emosional terhadap prestasi kerja dosen Sekolah Tinggi Maritim Yogyakarta. Adanya pengaruh positif, diketahui dari nilai koefisien regresi sebesar positif 0,549. Adanya pengaruh signifikan diketahui dari hasil uji $\mathrm{F}$ dan uji t yang mendapatkan nilai signifikansi 0,004 . Hasil pengujian ini menghasilkan kesimpulan ada pengaruh positif dan signifikan dari variabel kecerdasan emosional terhadap pretasi kerja dosen STIMARYO Yogyakarta (hipotesis terbukti).

Hasil uji $\mathrm{F}$ tersebut didukung oleh uji koefisien determinasi $\left(\mathrm{R}^{2}\right)$ yang mendapakan nilai $\mathrm{R}^{2}$ sebesar 0,466 . Artinya variansi variabel terikat yang dapat dijelaskan variabel bebas sebesar 46,6\% sedangkan yang 53,4\% dijelaskan oleh variabel lain yang tidak diteliti dalam penelitian ini.

\section{DAFTAR PUSTAKA}

Astriawati, N. (2016) 'Penerapan Analisis Regresi Linier Berganda Untuk Menentukan Pengaruh Pelayanan Pendidikan Terhadap Efektifitas Belajar Taruna Di Akademi Maritim Yogyakarta', Majalah Ilmiah Bahari Jogja, XIV(regresi liner), pp. 22-37. Available at: http://jurnal.amy.ac.id/index.php/MIBJ/article/view/90/89.

Azwar. S., (2009). Sikap Manusia Teori Dan Pengukuran, Edisi ke-2, Pustaka Pelajar, Yogyakarta.

Goleman, Daniel, (2005). Kecerdasan Emosi Untuk Mencapai Puncak Prestasi, Gramedia Pustaka Utama, Jakarta.

Martin, A.D., (2003). Emotional Quality Manajemen, Arga, Jakarta.

Melianawati, F.X. Sutyas Prihanto, A.J. Tjahjoanggoro (2001). Hubungan Kecerdasan Emosioanl dengan Kinerja Karyawan, Anima, Indonesia Psychological Journal, Vol. 17, No. 1, pp. 57-62.

Panggabean, M.S., Manajemen Sumber Daya Manusia, Ghalia Indonesia, Jakarta, 2002.

Permenpan dan Reformasi Birokrasi No. 46 Th. 2013 tentang Jabatan Fungsional Dosen dan Angka Kreditnya. 
Santoso, Singgih, (2007). Menguasai Statsistik di Era Reformasi dengan SPSS 15, Jakarta: PT. Elex Media Komputindo.

Simamora, H., Manajemen Sumber Daya Manusia, edisi kedua, Yogyakarta, Bagian Penerbitan STIE YKPN, 2003.

Sugiyanto, (1997). Sumber Daya Manusia dalam Sistem Masyarakat Industri dan Teknologi, Jurnal Psikologika, No. 4, Tahun II, 1997. 